\title{
Bacterial Biosynthesis of Gold Nanoparticles Using Salmonella enterica subsp. enterica serovar Typhi Isolated from Blood and Stool Specimens of Patients
}

\author{
Seyed Mojtabi Mortazavi ${ }^{1,5} \cdot$ Mehrdad Khatami $^{1,2,3}$. \\ Iraj Sharifi $^{2}$ Hossein Heli $^{3}$ - Keyghobad Kaykavousi ${ }^{4}$. \\ Mohammad Hossein Sobhani Poor ${ }^{4}$ Sam Kharazi ${ }^{5}$. \\ Marcos Augusto Lima Nobre ${ }^{6}$
}

Received: 25 May 2017/Published online: 26 July 2017

(C) Springer Science+Business Media, LLC 2017

\begin{abstract}
Salmonella is one of the most common causes of gastroenteritis. In this study, a PCR assay was developed for the rapid detection of microbial cultures of Salmonella enterica sub species of enterica serovar Typhi in samples of patients suspected typhoid. The assay was based on duplicate the STY4669-hypothetical protein gene. The gene primers were designed and blast. Then the bacteria strains were employed for the green synthesis of gold nanoparticles (AuNPs), and one of the strains represented ability to extracellular synthesis of gold nanoparticles. The nanoparticles were characterized using UV-visible spectrophotometer, X-ray powder diffraction, Transmission electron microscopy. The synthesized nanoparticles had a maximum absorption in UV-vis spectra at $556 \mathrm{~nm}$, a crystalline structure, and an average size of $42 \mathrm{~nm}$.
\end{abstract}

Electronic supplementary material The online version of this article (doi:10.1007/s10876-017-12670 ) contains supplementary material, which is available to authorized users.

$\triangle$ Mehrdad Khatami

M.khatami@mubam.ac.ir

$\bowtie$ Iraj Sharifi

iraj.sharifi@yahoo.com

1 School of Medicine, Bam University of Medical Sciences, Bam, Iran

2 Leishmaniasis Research Center, Kerman University of Medical Sciences, Kerman, Iran

3 Nanomedicine and Nanobiology Research Center, Shiraz University of Medical Sciences, Shiraz, Iran

4 Reaserch Center for Infectious and Tropical Diseases, Kerman University of Medical Sciences, Kerman, Iran

5 Reaserch Center for Infectious and Tropical Diseases, Zabol University of Medical Sciences, Zabol, Iran

6 Department of Physics, School of Technology and Sciences, Sao Paulo State University UNESP, P.O. Box 467, Presidente Prudente, SP 19060-900, Brazil 
Keywords Salmonella enterica $\cdot$ Gold nanoparticles · Extracellular synthesis · Molecular identification · AuNPs

\section{Introduction}

Diarrhea is a disease, which is a health/social dilemma in all parts of the world, especially in developing countries [1]. In these countries, diarrheal diseases causes nearly 5 million deaths, and Salmonella bacteria have an important contribution in this regard [2]. This disease is common among children and old people. Most species of Salmonella are potential pathogens for humans and many of animals [3, 4]. This species are placed in the gut of inflammatory diarrhea and food poisoning are considered [5]. The species are common in older children and adults. The bacteria have settled in the digestive system of vertebrates, including mammals, birds and fish and depending on the species, conditions and multiple factors of the host, can cause diseases with different symptoms and complications [3, 6-8]. Salmonella belongs to Entereobacteriaceae family and consists of 2200 species and more than $90 \%$ of species are human pathogens and other are animal pathogens, including typhi, typhimurium, enteritidis, Aynfantys species, etc. This is one of the most common bacteria transferred from animals to humans which has a variety of host species. It is also considered as one of the most important factors in diseases transmitted via food and one of the major public health problem around the world [3]. Therefore, early detection of diseases caused by these bacteria is extremely important $[9,10]$.

The field of nanobotechnology mainly encompasses with medicine, environment sciences and it develops novel therapeutic nanostructures for biomedical applications [11-18]. The biosynthesized nanomaterials such as copper, silver, gold, palladium, platinum, zinc oxide and magnetite nanoparticles have been effectively controlling the various pathogens [19-27]. In last decade, many studies have proved that the microbial extracts act as a potential precursor for the synthesis of nanomaterial in non-hazardous ways [28].

Due to the unique physicochemical properties of gold nanostructures such as optical, mechanical, and high surface to volume ratio, they have various applications in different fields including biosensors, microbiology, biotechnology, pharmacy, catalysis, etc. [29-37]. Biosynthesis of gold nanoparticles is important due to needing lower energy, simple equipments, and lower costs [38-46].

In present study, PCR was used for rapid detection of clinical samples of Salmonella enterica subsp. enterica serovar Typhi. Then, this species was employed as a biological source for the biosynthesis of gold nanoparticles which has never approached.

\section{Materials and Methods}

\section{Chemicals and Biologicals}

All chemicals were purchased from Merck (Germany) and used as received. 
Blood samples and applied stools of patients with diarrhea were received from Baghiat-Allah hospital (Tehran, Iran). The samples were transferred to selenite F medium and incubated for $10 \mathrm{~h}$ at $37^{\circ} \mathrm{C}$. The samples were then transferred to the medium of Salmonella-Shigella agar (SS), Xylose-Lysine Deoxychola agar (XLD) and MacConky agar, and incubated for $24 \mathrm{~h}$ at $37^{\circ} \mathrm{C}$. Suspected Salmonella colonies were identified and isolated by standard biochemical tests, TSI citrate Lysine Iron Agar, Urea and Methyl Red/Voges Proskauer (MR-VP). After those tests, the serotype tests were performed with antiserum [47]. First, the blood samples were cultured for $24-48 \mathrm{~h}$ in a biphasic (solid and liquid) medium and then were transferred to the medium of Blood Agar, Salmonella-Shigella agar (SS), Xylose-Lysine Deoxychola agar (XLD), and MacConky agar. After $24 \mathrm{~h}$, the suspected colonies were separated and then identified with the biochemical tests. To separate and confirm S. enterica serovar Typhi, the Serotyping test was conducted to determine the $\mathrm{O}$ and $\mathrm{H}$ antigens with specific antiserum of Staten Serum Institute (Denmark). After preparing the bacterial suspensions and adjacent to antiserum, in case of positive results, it was observed on the slide agglutination for $2 \min$ [48-50].

\section{Molecular Identification}

The sequences of forward and reverse primers are designed for molecular identification of bacteria STY4669-hypothetical protein gene. The genome DNA of clinical strains that was identified by biochemical and serologic methods were extracted and PCR was performed. To investigate the designed primers, the genomic DNA of other gram-positive Enterobacteriaceae bacteria strains was used.

\section{Culturing Bacteria for DNA Extraction}

After isolating and identifying, the bacteria were grown in Luria broth (LB) medium and incubated for $24 \mathrm{~h}$ in a shaking incubator. The turbidity of the tubes containing a liquid culture of bacteria was measured using a spectrophotometer. To isolate the cell mass of bacteria, the medium containing bacterial mass was centrifuged at $9000 \times g$ for $7 \mathrm{~min}$. The supernatant phase containing medium was removed and deposited bacterial cell mass was collected. $3 \mathrm{~mL}$ proteinase $\mathrm{K}(20 \mathrm{mg} / \mathrm{mL}), 13 \mathrm{~mL}$ sodium dodecyl sulfate (SDS, 20\%) and $620 \mathrm{~mL}$ tampons lysis were added to the cell mass of the bacteria deposited in microtubes, and incubated for $1 \mathrm{~h}$ at $60{ }^{\circ} \mathrm{C}$ in bain-marie medium. This solution was relatively clear, indicating lysis of bacterial cells. Then, $620 \mathrm{~mL}$ of phenol-chloroform-isoamylic alcohol were added to microtubes containing bacterial lysate solution from the previous step with ratios of $1: 24: 25$. The microtubes were shaken gently to attain milky solutions. The solutions were then centrifuged at $10,000 \times g$ for $10 \mathrm{~min}$. At the end of this phase, threephase was formed: bacterial genomes in upper phase, proteins in interphase, and phenol-chloroform-isoamylic alcohol at the lower region. The upper and clear liquid supernatant was separated and the residues of phenol was eliminated by adding $620 \mathrm{~mL}$ of chloroform and then centrifuged. The upper phase was transferred to microtubes, cold pure ethanol was added and gently inverted several times to appear DNA strands. The microtubes were centrifuged at $10,000 \times g$ for 
$10 \mathrm{~min}$ at $4{ }^{\circ} \mathrm{C}$. Finally, the upper phase was discarded and $100 \mathrm{~mL}$ TE solution was added to sediment and gently shacked [51, 52]. The purified DNA was stored at $-20{ }^{\circ} \mathrm{C}$. Concentration and purity of DNA samples were evaluated by UV absorption.

\section{Primers Design and PCR Procedures}

Firstly, the gene sequence of STY4669-hypothetical protein was extracted from NCBI database and the primers were designed by Primer3 software (Table 1). The accuracy and specificity of the designed primer sequences were checked in Blast database and eventually synthesized Blast.

PCR steps (Master cycler gradient) included as follows [53]:

- Denaturation at $94{ }^{\circ} \mathrm{C}$ for $5 \mathrm{~min}$

- Repeating 30 temperature cycle to amplify DNA. Each cycle consists of:

1. $95^{\circ} \mathrm{C}$ for $1 \mathrm{~min}$

2. $59{ }^{\circ} \mathrm{C}$ for $1 \mathrm{~min}$

3. $72{ }^{\circ} \mathrm{C}$ for $1 \mathrm{~min}$

- Storing at $72{ }^{\circ} \mathrm{C}$ for $10 \mathrm{~min}$

- Storing at $4{ }^{\circ} \mathrm{C}$ for $2 \mathrm{~h}$

$5 \mathrm{~mL}$ of the PCR product was electrophoresed to verify the amplification reaction. After seeing the amplified fragment with a size of about 489, PCR product was sequenced by Bioneer (Korea).

\section{Biosynthesis of Gold Nanoparticles}

After isolation and identification of S. enterica subsp. enterica serovar Typhi, the cells were dissolved in $5 \mathrm{~mL}$ double distilled water. $10 \mathrm{~mL}$ of $1 \mathrm{mM} \mathrm{HAuCl} 4$ solution was added to $1 \mathrm{~mL}$ bacteria lysed cells at $25{ }^{\circ} \mathrm{C}$ and was kept in dark. The color of the mixture gradually changed to reddish-purple.

\section{Characterization of the Gold Nanoparticles}

The optical properties of biosynthesized gold nanoparticles were studied by using UV-visible Spectrophotometer (Nanodrop, Analytik jena, Germany). The phase

Table 1 The properties of used pair primers

\begin{tabular}{lllll}
\hline $\begin{array}{l}\text { Size } \\
(\mathrm{bp})\end{array}$ & $\begin{array}{l}\mathrm{T}_{\mathrm{M}} \\
\left({ }^{\circ} \mathrm{C}\right)\end{array}$ & $\begin{array}{l}\text { Length } \\
(\mathrm{b})\end{array}$ & Primers sequence & Gene type \\
\hline 489 & 62 & 21 & $\begin{array}{l}\text { F: } 5^{\prime} \text { - TGTCCGCTGTCTGAAGTCATC-3' } \\
\text { R: } 5^{\prime} \text {-ATCTCAGGCAAACTCACAAGG } \\
\text { G-3' }\end{array}$ & $\begin{array}{c}\text { STY4669 - hypothetical } \\
\text { protein gene }\end{array}$ \\
\hline
\end{tabular}


formation of gold nanoparticles were examined by XRD technique using a X-ray diffractometer (Phillips, Holland) over a wide range of Bragg angles 20-80, $2 \theta$ with $\mathrm{CuKa}$ radiation $\mathrm{k}=1.5405 \mathrm{~A}^{\circ}$. The size, distribution and shape of synthesized gold nanoparticles were characterized using TEM (Carl ZIESS, Germany).

\section{Results}

The extracted DNA samples were confirmed to be pure by electrophoresis without RNA contamination (Supplementary material S1). In addition, the ratio of optical density measured at $260-280 \mathrm{~nm}$ was obtained as 1.73 , further confirmed the purity of the extracted DNA samples.

First, the best PCR conditions were optimized and the best temperature $\left(59^{\circ}\right)$, and $\mathrm{MgCl}_{2}$ concentration $(5.0 \mathrm{~mL}$ ) was determined (Fig. 1).

The amplified genes (Fig. 2) were sequenced. The obtained sequences from the NCBI BLAST database indicated $100 \%$ similarity in S. enterica subsp. enterica serovar Typhi. The effect of PCR reaction with the designed primers was studied on some of Enterobacteriaceae bacteria (Escherichia coli, Shigella, Proteus, Klebsiella) and gram-positive cocci of Staphylococcus aureus. The results are presented in Fig. 3 and indicated that the primer sets were unique and can be reproduced only in S. enterica subsp. enterica serovar Typhi.

During the biosynthesis of the gold nanoparticles, reddish-purple color was firstly observed (Fig. 4b). UV-vis spectrophotometry of the synthesized solution showed absorption peak with a maximum at $556 \mathrm{~nm}$, as shown in Fig. 4.

$\mathrm{X}$-ray diffraction pattern of the gold nanoparticles is presented in Fig. 5 containing strong peaks at $2 \theta$ values of $38,44,64$ and $77^{\circ}$. These peaks are assigned to the crystal planes of ( $\left.\begin{array}{lll}1 & 1 & 1\end{array}\right),\left(\begin{array}{lll}2 & 0 & 0\end{array}\right),\left(\begin{array}{lll}2 & 2 & 0\end{array}\right)$, and (3 111$)$, respectively.

Fig. 1 Salmonella enterica subsp. enterica serovar Typhi band and species-specific PCR product bp 489 reproduced in different concentrations in order from left to right, $1,9.0,5 / 0,4.0$ and $3.0 \mathrm{~mL} \mathrm{MgCl}_{2}$. In addition, in the pit Ladder No. 6 bp100. After PCR reaction in optimum condition, the fragment containing the sequence STY4669 -hypothetical protein of $S$. enterica subsp. enterica serovar Typhi was designed from clinical strains

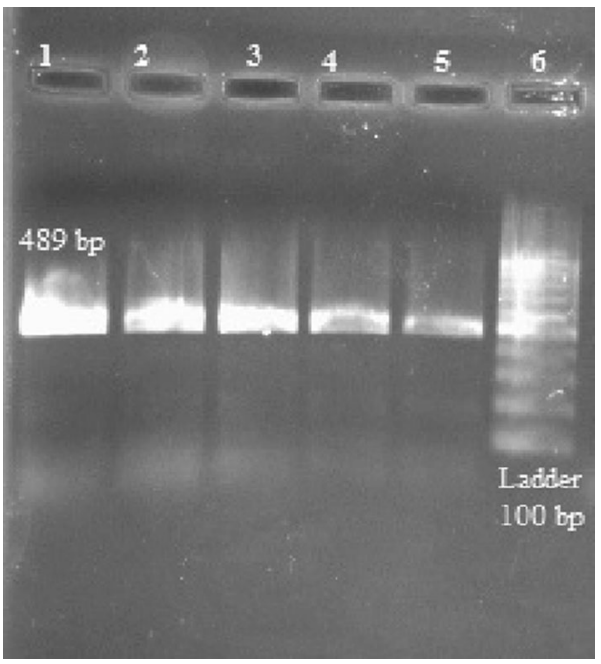


Fig. 2 The image of amplified

S. enterica subsp. enterica serovar Typhi from $489 \mathrm{bp}$ strain (Well 2), and $100 \mathrm{bp}$ markers (Well No. 1)
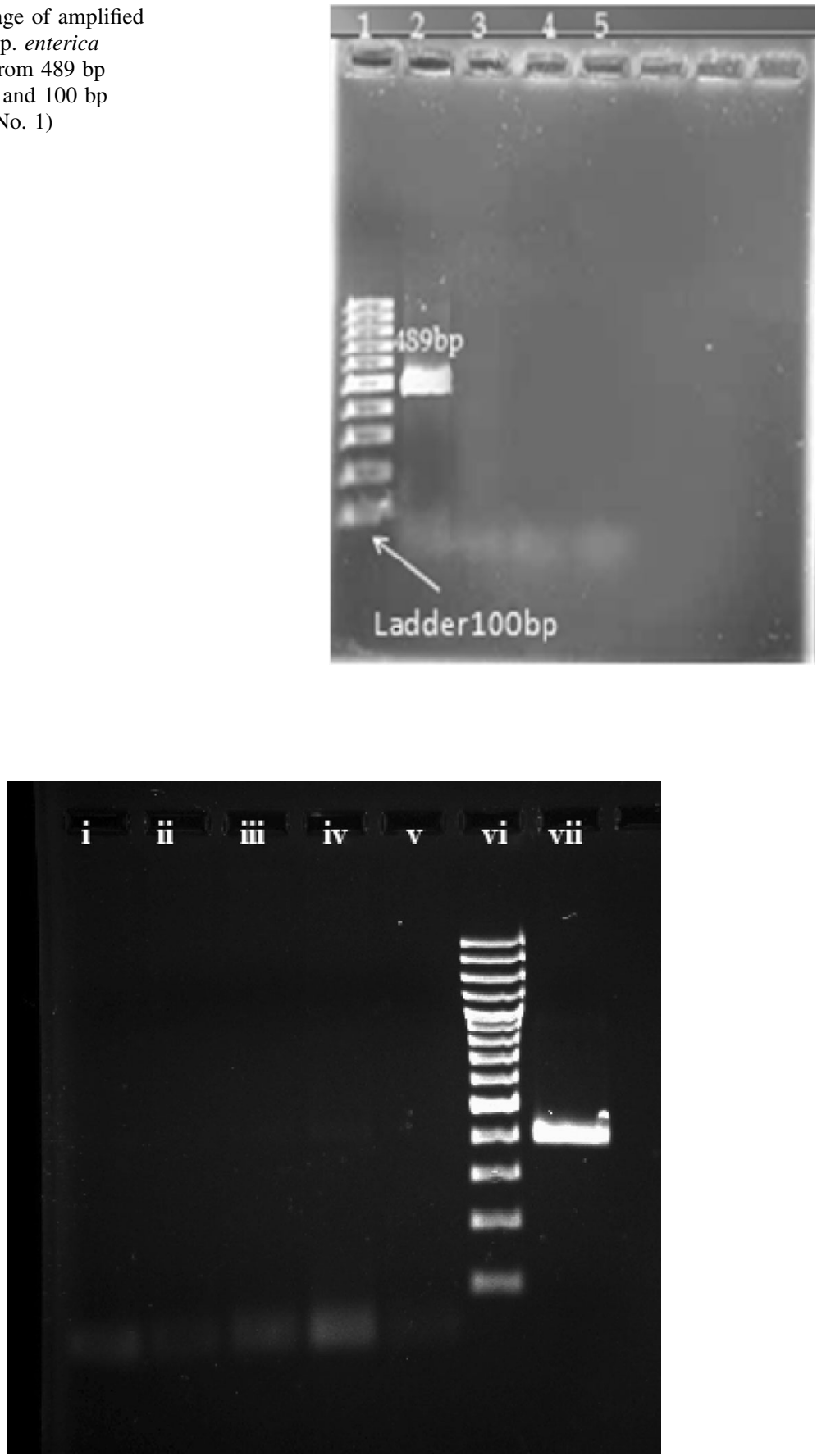

Fig. 3 PCR of designed primers on the genetic material of other bacterial species. (i) Escherichia coli, (ii) Proteus bacteria, (iii) Shigella, (iv) Klebsiella bacteria, (v) Staphylococcus aureus bacteria, grampositive cocci, (vi) Ladder 100, (vii) and the positive control 


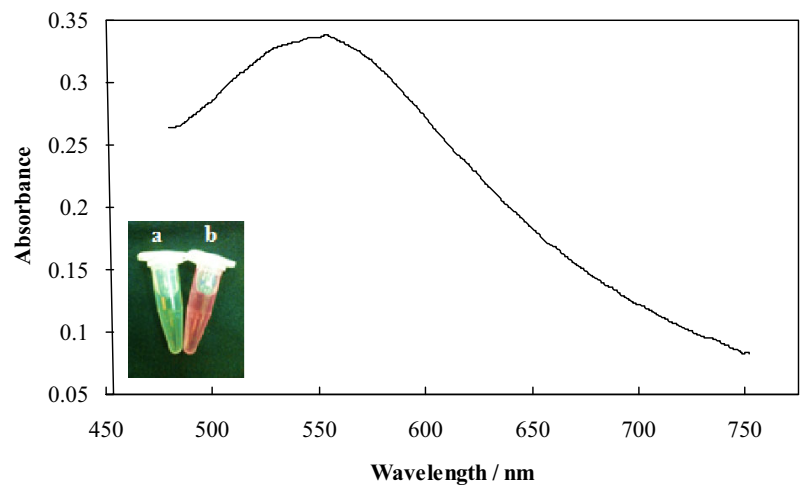

Fig. 4 UV-Vis spectrum of the gold nanoparticles (b) synthesized using extracellular content of Salmonella typhimurium (a)



Fig. 5 X-ray diffraction pattern of the gold nanoparticles synthesized using S. enterica subsp. enterica serovar Typhi

A TEM image of the nanoparticles is shown in Fig. 6. The gold particles had an average size of $42 \pm 2 \mathrm{~nm}$.

\section{Discussion}

Salmonella is one of the most important causes of gastroenteritis in the world. Fast and accurate detection of these bacteria in food and patients can prevent the spread of these bacteria. Traditional methods of detection of the bacterium are often time consuming and always problematic for microbiologists, especially when quick results announcement is economically and medically crucial. The PCR method is one of the fast and secure methods of molecular identification to amplify and detect a separated genetic locus. 
Fig. 6 A TEM image of gold nanoparticles synthesized using extracellular content of $S$. enterica subsp. enterica serovar Typhi

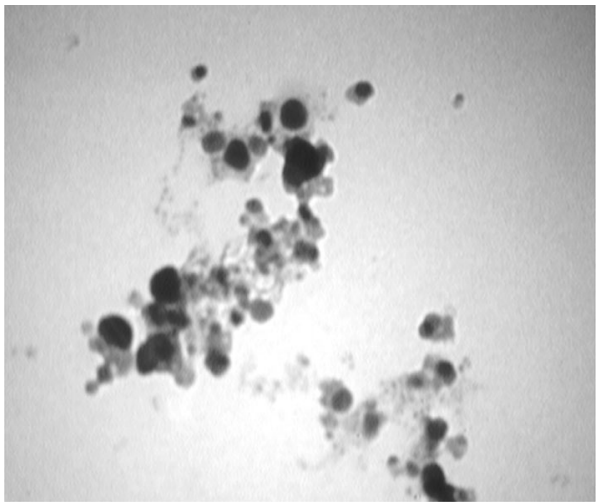

Trokv et al. [54] used srRNA 16 (16srRNA) and Pathmanathan et al. [55] used hilA gene to identify Salmonella without identification of species, while specific detection of bacteria in clinical samples is required. In recent years, Au nanoparticle were used widely in order to design biosensors for the detection of pathogens [56]. These results provided a situation for future studies and scientists can use $\mathrm{Au}$ nanoparticles and biosensors for the rapid detection of microbial strains like Chang et al. [57] who recognized Staphylococcus aureus in 1 and half hour since Au nanoparticles attached to the aptamer. Also Wu et al. [58] have designed and reported two rapid and sensitive detection methods for $S$. enterica subsp. enterica serovar Typhi by Au nanoparticles attached to antibodies.

Acknowledgements The study was supported by a research facility from: Leishmaniasis Research Center, Kerman University of Medical Sciences, Kerman, Iran and Comprehensive laboratory research, Bam University of Medical Sciences Bam, Iran.

\section{Compliance with Ethical Standards}

Conflict of interest The authors confirm that this article content has no competing interests.

\section{References}

1. A. V. Kulinkina, V. R. Mohan, M. R. Francis, D. Kattula, R. Sarkar, J. D. Plummer, H. Ward, G. Kang, V. Balraj, and E. N. Naumova (2016). Seasonality of water quality and diarrheal disease counts in urban and rural settings in south India. Sci. Rep. 6, 20521.

2. R. E. Black (1984). Diarrheal diseases and child morbidity and mortality. Popul. Dev. Rev. 10, $141-161$.

3. M. Ejo, L. Garedew, Z. Alebachew, and W. Worku (2016). Prevalence and antimicrobial resistance of Salmonella isolated from animal-origin food items in Gondar, Ethiopia. Biomed. Res. Int. 2016, 8.

4. A. M. Leahy, K. J. Cummings, L. D. Rodriguez-Rivera, S. C. Rankin, and S. A. Hamer (2016). Evaluation of faecal Salmonella shedding among dogs at seven animal shelters across Texas. Zoonoses Public Health 63, (7), 515-521.

5. Z. A. Anteneh, K. Andargie, and M. Tarekegn (2017). Prevalence and determinants of acute diarrhea among children younger than five years old in Jabithennan District, Northwest Ethiopia, 2014. BMC Public Health 17, (1), 99. 
6. D. E. Cosby, N. A. Cox, M. A. Harrison, J. L. Wilson, R. J. Buhr, and P. J. Fedorka-Cray (2015). Salmonella and antimicrobial resistance in broilers: a review. J. Appl. Poult. Res. 24, (3), 408-426.

7. Y. Li, Y. Li, X. Cao, X. Jin, and T. Jin (2017). Pattern recognition receptors in zebrafish provide functional and evolutionary insight into innate immune signaling pathways. Cell. Mol. Immunol. 14, (1), 80-89.

8. N. Seepersadsingh and A. A. Adesiyun (2003). Prevalence and antimicrobial resistance of Salmonella spp. in pet mammals, reptiles, fish aquarium water, and birds in Trinidad. J. Vet. Med. Ser. B 50, (10), 488-493.

9. S. S. Meymandi, M. Bahmanyar, S. Dabiri, M. R. Aflatonian, S. Bahmanyar, and M. S. Meymandi (2010). Comparison of cytologic giemsa and real-time polymerase chain reaction technique for the diagnosis of cutaneous leishmaniasis on scraping smears. Acta Cytol. 54, (4), 539-545.

10. R. Ahmadrajabi, M. R. Shakibaie, Z. Iranmanesh, H. R. Mollaei, and M. H. Sobhanipoor (2016). Prevalence of mip virulence gene and PCR-base sequence typing of Legionella pneumophila from cooling water systems of two cities in Iran. Virulence 7, (5), 602-609.

11. P. Kuppusamy, M. M. Yusoff, G. P. Maniam, and N. Govindan (2016). Biosynthesis of metallic nanoparticles using plant derivatives and their new avenues in pharmacological applications: an updated report. Saudi Pharm. J. 24, (4), 473-484.

12. G. Abedi, A. Sotoudeh, M. Soleymani, A. Shafiee, P. Mortazavi, and M. R. Aflatoonian (2011). A collagen-poly(vinyl alcohol) nanofiber scaffold for cartilage repair. J. Biomater. Sci. Polym. Ed. 22, (18), 2445-2455.

13. H. Mahmoudvand, M. Fasihi Harandi, M. Shakibaie, M. R. Aflatoonian, N. ZiaAli, M. S. Makki, and S. Jahanbakhsh (2014). Scolicidal effects of biogenic selenium nanoparticles against protoscolices of hydatid cysts. Int. J. Surg. 12, (5), 399-403.

14. S. P. Moussavi, M. H. Ehrampoush, A. H. Mahvi, S. Rahimi, and M. Ahmadian (2014). Efficiency of multi-walled carbon nanotubes in adsorbing humic acid from aqueous solutions. Asian J. Chem. 26, (3), 821-826.

15. M. T. Samadi, H. Zolghadrnasab, K. Godini, A. Poormohammadi, M. Ahmadian, and S. Shanesaz (2015). Kinetic and adsorption studies of reactive black 5 removal using multi -walled carbon nanotubes from aqueous solution. Der Pharm. Chem. 7, (5), 267-274.

16. M. Ahmadian, S. Reshadat, N. Yousefi, S. H. Mirhossieni, M. R. Zare, S. R. Ghasemi, N. Rajabi Gilan, R. Khamutian, and A. Fatehizadeh (2013). Municipal leachate treatment by Fenton process: effect of some variable and kinetics. J. Environ. Public Health 2013, 6.

17. T. Ghodselahi, T. Neishaboorynejad, and S. Arsalani (2015). Fabrication LSPR sensor chip of Ag NPs and their biosensor application based on interparticle coupling. Appl. Surf. Sci. 343, 194-201.

18. H. Heli, M. Zarghan, A. Jabbari, A. Parsaei, and A. A. Moosavi-Movahedi (2010). Electrocatalytic oxidation of the antiviral drug acyclovir on a copper nanoparticles-modified carbon paste electrode. $J$. Solid State Electrochem. 14, (5), 787-795.

19. M. Khatami, H. Heli, P. M. Jahani, H. Azizi and M. L. Nobre, Copper/copper oxide nanoparticles synthesis using Stachys lavandulifolia and its antibacterial activity, in IET Nanobiotechnology (Institution of Engineering and Technology, 2017).

20. E. Zare, S. Pourseyedi, M. Khatami, and E. Darezereshki (2017). Simple biosynthesis of zinc oxide nanoparticles using nature's source, and it's in vitro bio-activity. J. Mol. Struct. 1146, 96-103.

21. M. Khatami and S. Pourseyedi, Phoenix dactylifera (date palm) pit aqueous extract mediated novel route for synthesis high stable silver nanoparticles with high antifungal and antibacterial activity, in IET Nanobiotechnology, vol. 9 (Institution of Engineering and Technology, 2015) pp. 184-190.

22. M. Khatami, E. Amini, A. Amini, S. M. Mortazavi, Z. Kishani Farahani, and H. Heli (2017). Biosynthesis of silver nanoparticles using pine pollen and evaluation of the antifungal efficiency. Iran. J. Biotechnol. 15, (2), 1-7.

23. Z. Azizi, S. Pourseyedi, M. Khatami, and H. Mohammadi (2016). Stachys lavandulifolia and Lathyrus sp. mediated for green synthesis of silver nanoparticles and evaluation its antifungal activity against dothiorella sarmentorum. J. Clust. Sci. 27, (5), 1613-1628.

24. M. S. Nejad, G. H. S. Bonjar, M. Khatami, A. Amini and S. Aghighi, In vitro and in vivo antifungal properties of silver nanoparticles against Rhizoctonia solani, a common agent of rice sheath blight disease, in IET Nanobiotechnology, vol. 11 (Institution of Engineering and Technology, 2017) pp. 236-240.

25. M. Khatami, R. Mehnipor, M. H. S. Poor, and G. S. Jouzani (2016). Facile biosynthesis of silver nanoparticles using descurainia sophia and evaluation of their antibacterial and antifungal properties. J. Clust. Sci. 27, (5), 1601-1612. 
26. S. Hashemi, Z. Asrar, S. Pourseyedi and N. Nadernejad, Green synthesis of ZnO nanoparticles by olive (Olea europaea), in IET Nanobiotechnology, vol. 10 (Institution of Engineering and Technology, 2016) pp. 400-404.

27. S. Hashemi, Z. Asrar, S. Pourseyedi, and N. Nadernejad (2016). Plant-mediated synthesis of zinc oxide nano-particles and their effect on growth, lipid peroxidation and hydrogen peroxide contents in soybean. Indian J. Plant Physiol. 21, (3), 312-317.

28. M. S. Nejad, M. Khatami and G. H. S. Bonjar, Extracellular synthesis gold nanotriangles using biomass of Streptomyces microflavus, in IET Nanobiotechnology, vol. 10 (Institution of Engineering and Technology, 2016) pp. 33-38.

29. A. Rahi, N. Sattarahmady, and H. Heli (2015). Zepto-molar electrochemical detection of Brucella genome based on gold nanoribbons covered by gold nanoblooms. Sci. Rep. 5, 18060.

30. Y.-C. Wang, L. Lu, and S. Gunasekaran (2017). Biopolymer/gold nanoparticles composite plasmonic thermal history indicator to monitor quality and safety of perishable bioproducts. Biosens. Bioelectron. 92, 109-116.

31. J. N. Payne, H. K. Waghwani, M. G. Connor, W. Hamilton, S. Tockstein, H. Moolani, F. Chavda, V. Badwaik, M. B. Lawrenz, and R. Dakshinamurthy (2016). Novel synthesis of kanamycin conjugated gold nanoparticles with potent antibacterial activity. Front. Microbiol. 7, 607.

32. C. Yao, L. Zhang, J. Wang, Y. He, J. Xin, S. Wang, H. Xu, and Z. Zhang (2016). Gold nanoparticle mediated phototherapy for cancer. J. Nanomater. 2016, 29.

33. R. Schreiber, I. Santiago, A. Ardavan, and A. J. Turberfield (2016). Ordering gold nanoparticles with DNA origami nanoflowers. ACS Nano 10, (8), 7303-7306.

34. H. N. McQuaid, M. F. Muir, L. E. Taggart, S. J. McMahon, J. A. Coulter, W. B. Hyland, S. Jain, K. T. Butterworth, G. Schettino, K. M. Prise, et al. (2016). Imaging and radiation effects of gold nanoparticles in tumour cells. Sci. Rep. 6, 19442.

35. Q. Yu, J. Li, Y. Zhang, Y. Wang, L. Liu, and M. Li (2016). Inhibition of gold nanoparticles (AuNPs) on pathogenic biofilm formation and invasion to host cells. Sci. Rep. 6, 26667.

36. M. A. Zaimy, N. Saffarzadeh, A. Mohammadi, H. Pourghadamyari, P. Izadi, A. Sarli, L. K. Moghaddam, S. R. Paschepari, H. Azizi, S. Torkamandi, et al. (2017). New methods in the diagnosis of cancer and gene therapy of cancer based on nanoparticles. Cancer Gene Ther. 24, (6), 233-243.

37. M. A. Zaimy, A. Jebali, B. Bazrafshan, S. Mehrtashfar, S. Shabani, A. Tavakoli, S. H. Hekmatimoghaddam, A. Sarli, H. Azizi, P. Izadi, et al. (2016). Coinhibition of overexpressed genes in acute myeloid leukemia subtype M2 by gold nanoparticles functionalized with five antisense oligonucleotides and one anti-CD33(+)/CD34(+) aptamer. Cancer Gene Ther. 23, (9), 315-320.

38. M. Goudarzi, N. Mir, M. Mousavi-Kamazani, S. Bagheri, and M. Salavati-Niasari (2016). Biosynthesis and characterization of silver nanoparticles prepared from two novel natural precursors by facile thermal decomposition methods. Sci. Rep. 6, 32539.

39. M. Kumari, A. Mishra, S. Pandey, S. P. Singh, V. Chaudhry, M. K. R. Mudiam, S. Shukla, P. Kakkar, and C. S. Nautiyal (2016). Physico-chemical condition optimization during biosynthesis lead to development of improved and catalytically efficient gold nano particles. Sci. Rep. 6, 27575.

40. M. Green, S. J. Haigh, E. A. Lewis, L. Sandiford, M. Burkitt-Gray, R. Fleck, G. Vizcay-Barrena, L. Jensen, H. Mirzai, R. J. Curry, et al. (2016). The biosynthesis of infrared-emitting quantum dots in allium fistulosum. Sci. Rep. 6, 20480.

41. A. Miri, M. Sarani, M. Rezazade Bazaz, and M. Darroudi (2015). Plant-mediated biosynthesis of silver nanoparticles using Prosopis farcta extract and its antibacterial properties. Spectrochim. Acta Part A Mol. Biomol. Spectrosc. 141, 287-291.

42. M. Darroudi, M. Sarani, R. Kazemi Oskuee, A. Khorsand Zak, and M. S. Amiri (2014). Nanoceria: gum mediated synthesis and in vitro viability assay. Ceram. Int. 40, (2), 2863-2868.

43. S. Hamedi, S. A. Shojaosadati, S. Shokrollahzadeh and S. Hashemi-Najafabadi, Mechanism study of silver nanoparticle production using Neurospora intermedia, in IET Nanobiotechnology, vol. 11 (Institution of Engineering and Technology, 2017) pp. 157-163.

44. S. Hamedi, S. A. Shojaosadati, and A. Mohammadi (2017). Evaluation of the catalytic, antibacterial and anti-biofilm activities of the Convolvulus arvensis extract functionalized silver nanoparticles. $J$. Photochem. Photobiol. B 167, 36-44.

45. S. Hamedi, M. Ghaseminezhad, S. Shokrollahzadeh, and S. A. Shojaosadati (2016). Controlled biosynthesis of silver nanoparticles using nitrate reductase enzyme induction of filamentous fungus and their antibacterial evaluation. Artif. Cells Nanomed. Biotechnol. 44, 1-9. 
46. F. Baghbani, F. Moztarzadeh, J. A. Mohandesi, F. Yazdian, M. Mokhtari-Dizaji, and S. Hamedi (2016). Formulation design, preparation and characterization of multifunctional alginate stabilized nanodroplets. Int. J. Biol. Macromol. 89, 550-558.

47. M. M. Soltan Dallal, A. Rastegar Lari, and M. K. Sharifi Yazdi (2014). Pattern of serotyping and antibiotic resistance of Salmonella in children with diarrhea. J. Gorgan Univ. Med. Sci. 16, (1), $100-105$.

48. S. J. Olsen, J. Pruckler, W. Bibb, N. T. M. Thanh, T. M. Trinh, N. T. Minh, S. Sivapalasingam, A. Gupta, P. T. Phuong, N. T. Chinh, et al. (2004). Evaluation of rapid diagnostic tests for typhoid fever. J. Clin. Microbiol. 42, (5), 1885-1889.

49. J. Wain, T. S. Diep, V. A. Ho, A. M. Walsh, N. T. T. Hoa, C. M. Parry, and N. J. White (1998). Quantitation of bacteria in blood of typhoid fever patients and relationship between counts and clinical features, transmissibility, and antibiotic resistance. J. Clin. Microbiol. 36, (6), 1683-1687.

50. J. R. McQuiston, R. J. Waters, B. A. Dinsmore, M. L. Mikoleit, and P. I. Fields (2011). Molecular determination of $\mathrm{H}$ antigens of Salmonella by use of a microsphere-based liquid array. J. Clin. Microbiol. 49, (2), 565-573.

51. F. Vorreiter, S. Richter, M. Peter, S. Baumann, M. von Bergen, and J. M. Tomm (2016). Comparison and optimization of methods for the simultaneous extraction of DNA, RNA, proteins, and metabolites. Anal. Biochem. 508, 25-33.

52. H.-R. Cheng and N. Jiang (2006). Extremely rapid extraction of DNA from bacteria and yeasts. Biotech. Lett. 28, (1), 55-59.

53. M. D. Kulinski, M. Mahalanabis, S. Gillers, J. Y. Zhang, S. Singh, and C. M. Klapperich (2009). Sample preparation module for bacterial lysis and isolation of DNA from human urine. Biomed. Microdevice 11, (3), 671-678.

54. M. Trkov and G. Avguštin (2003). An improved 16S rRNA based PCR method for the specific detection of Salmonella enterica. Int. J. Food Microbiol. 80, (1), 67-75.

55. S. G. Pathmanathan, N. Cardona-Castro, M. M. Sánchez-Jiménez, M. M. Correa-Ochoa, S. D. Puthucheary, and K. L. Thong (2003). Simple and rapid detection of Salmonella strains by direct PCR amplification of the hilA gene. J. Med. Microbiol. 25, (9), 773-776.

56. M. Lin, H. Pei, F. Yang, C. Fan, and X. Zuo (2013). Applications of gold nanoparticles in the detection and identification of infectious diseases and biothreats. Adv. Mater. 25, (25), 3490-3496.

57. Y.-C. Chang, C.-Y. Yang, R.-L. Sun, Y.-F. Cheng, W.-C. Kao, and P.-C. Yang (1863). Rapid single cell detection of Staphylococcus aureus by aptamer-conjugated gold nanoparticles. Sci. Rep. 2013, 3.

58. W. Wu, J. Li, D. Pan, J. Li, S. Song, M. Rong, Z. Li, J. Gao, and J. Lu (2014). Gold nanoparticlebased enzyme-linked antibody-aptamer sandwich assay for detection of Salmonella Typhimurium. ACS Appl. Mater. Interfaces 6, (19), 16974-16981. 